\title{
A potential bioconversion of empty fruit bunches into organic fertilizer using Eudrilus eugeniae
}

\author{
P. N. Lim • T. Y. Wu • C. Clarke • N. N. Nik Daud
}

Received: 29 December 2012/Revised: 16 January 2014/ Accepted: 8 July 2014/Published online: 8 August 2014

(C) Islamic Azad University (IAU) 2014

\begin{abstract}
Vermicomposting is a process to biotransform organic solid wastes into valuable product, namely vermicompost using epigeic earthworms. Vermicomposting technology may provide a low-input basis for sustainable management of organic solid waste. The present study was to investigate the suitability of oil palm empty fruit bunches to be reused as feedstocks of Eudrilus eugeniae for the duration of 12 weeks. Empty fruit bunches were mixed with cow dung in different ratios to produce five different treatments for laboratory screening of solid waste. The growths of E. eugeniae were monitored weekly. All treatments encouraged the growth of E. eugeniae except the treatment with empty fruit bunches alone. The maturity and quality of vermicompost were assessed through carbon-tonitrogen ratio, calcium, phosphorus, potassium and magnesium. Generally, all treatments showed increases in total contents of calcium (39.38-373.17\%), phosphorus (15.15-390.54\%), potassium (45.55-153.66\%) and magnesium $(55.86-370.93 \%)$ but a decrease in carbon-tonitrogen ratio (11.24-76.24\%) after 12 weeks of vermicomposting process. Besides, parameters such as $\mathrm{pH}$ and electrical conductivity were also investigated in this paper.
\end{abstract}

P. N. Lim · T. Y. Wu ( $($ )

Chemical Engineering Discipline, School of Engineering,

Monash University, Jalan Lagoon Selatan, 46150 Bandar

Sunway, Selangor Darul Ehsan, Malaysia

e-mail: wu.ta.yeong@monash.edu

C. Clarke

School of Science, Monash University, Jalan Lagoon Selatan, 46150 Bandar Sunway, Selangor Darul Ehsan, Malaysia

\section{N. N. Nik Daud}

Department of Civil Engineering, Faculty of Engineering, Universiti Putra Malaysia, 43400 Serdang, Selangor Darul Ehsan, Malaysia
Among all the treatments investigated, empty fruit bunches that were mixed with cow dung in the ratio of $2: 1$ were biotransformed into the most superior quality vermicompost (carbon-to-nitrogen ratio, 18.53; calcium, $7.76 \mathrm{~g} / \mathrm{kg}$; phosphorus, $3.63 \mathrm{~g} / \mathrm{kg}$; potassium, $12.81 \mathrm{~g} / \mathrm{kg}$; and magnesium, $4.05 \mathrm{~g} / \mathrm{kg}$ ). In conclusion, vermicomposting could be used as an efficient technology to convert empty fruit bunches into nutrient-rich organic fertilizers if the wastes were mixed with cow dung in an appropriate ratio.

Keywords Cleaner production - Cow dung - Epigeic earthworm - Solid waste management - Vermicomposting . Waste reuse

\section{Introduction}

Malaysian palm oil industry is growing rapidly and quickly becoming a significant agriculture-based industry in this country (Wu et al. 2010). In 2012, Malaysia has a total of over 5.0 million hectares of oil palm plantations, consisting of 4.3 and 0.7 million hectares of mature and immature oil palms, respectively (USDA 2012). The production of 1 tonne of crude palm oil requires 5 tonnes of fresh fruit bunches (Stichnothe and Schuchardt 2011). Thus, the high exports of Malaysian palm oil to southeast Asia (Fig. 1) or globally (Fig. 2) are reflecting the importance of fresh fruit bunches in Malaysia. In total, the palm oil industry contributes significantly toward the country's foreign exchange earnings and the increased standard living among Malaysians (Wu et al. 2009).

With the economic, industrial and agricultural development, environmental pollution has become an increasingly serious issue in the developing countries (Zhao et al. 2013), including Malaysia. In 2012, a total of about 92.3 


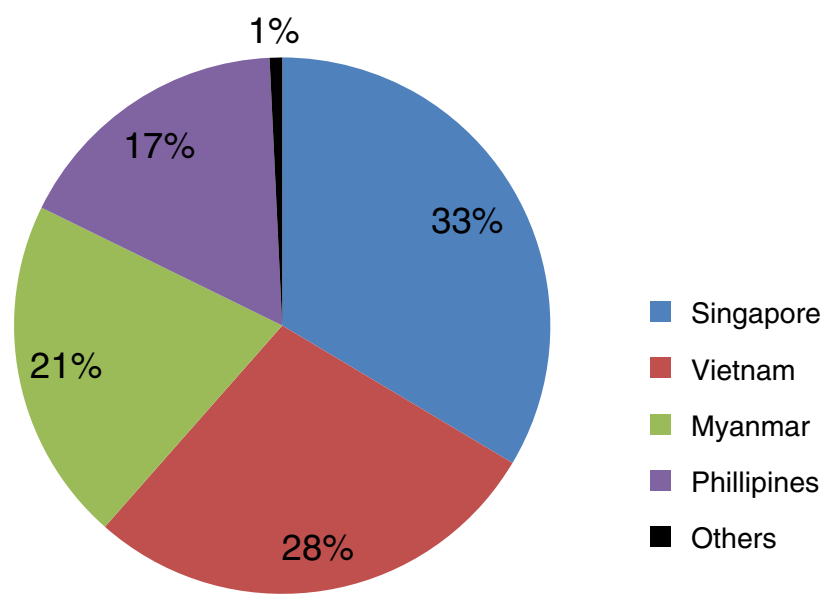

Fig. 1 Export of Malaysian palm oil ( $\sim 1.68$ million tonnes) to major countries in southeast Asia in 2012. Other countries include Brunei, Cambodia, Indonesia and Laos

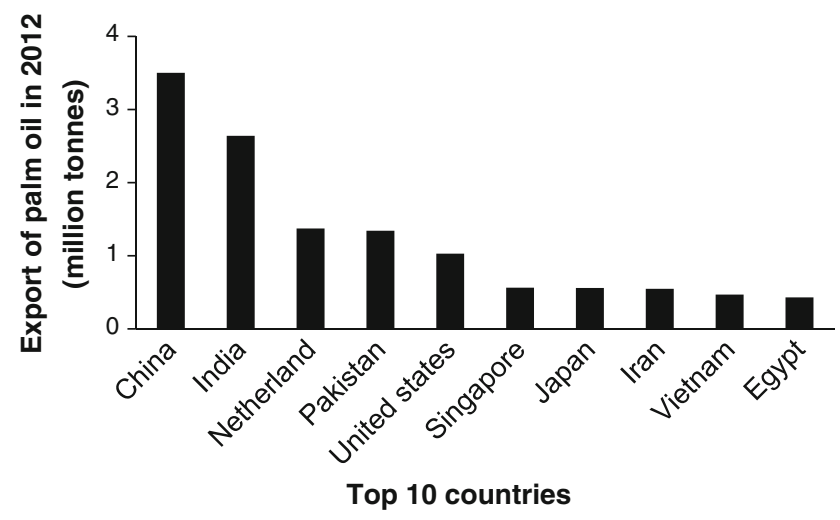

Fig. 2 Top 10 importers of Malaysian palm oil in 2012

million tonnes of fresh fruit bunches were processed in the palm oil mills (MPOB 2012), resulting in large amount of oil palm solid wastes generations, particularly palm nut shell (6\%), palm press fiber (30\%), empty fruit bunches $(28.5 \%)$ and decanter cake $(3 \%)$ are being generated during palm oil milling process (Pleanjai et al. 2004). The usual way to dispose oil palm solid wastes is by burning, so that the wastes could be reused for steam or power generation at the palm oil mills. However, empty fruit bunches have not been optimally used because they are wet and bulky, which are not suitable for burning and transportation. Although empty fruit bunches have the potential to be reused as mulch for oil palms, the improper stacking of empty fruit bunches on land may become the breeding site for pests such as rhinoceros beetles and rats. Furthermore, the direct application of empty fruit bunches on land could result in pollution of the surrounding area because these wastes still contain residual oil, which can be distributed through local environment (Kananam et al. 2011), especially during rainy season. Thus, managing empty fruit bunches from palm oil industry becomes a major challenge for local government as well as industries in Malaysia.

Waste management systems are generally influenced by socioeconomic, political and environmental factors, including population growth, consumption pattern and technological development of the waste systems (Zaman 2013b). In many countries, both energy and waste management systems are under changes (Nouri et al. 2012). Currently, a number of studies have been conducted by different researchers on the 'zero waste' concept (Zaman 2013a). In Malaysia, several different approaches have been attempted to explore the potentials for reusing empty fruit bunches as main feedstocks or substrates to produce activated carbon (Firoozian et al. 2011), bioethanol (Abu Bakar et al. 2012), biohydrogen (Chong et al. 2013), bio-oil (Abdullah et al. 2010), biochar (Samsuri et al. 2014), citric acid (Alam et al. 2010), composite (Bakar et al. 2010), lignophenol (Abdullah et al. 2009), xylose (Tan et al. 2013) and others. As empty fruit bunches contain high organic matter and mineral contents, these wastes are also currently being investigated as potential feedstocks in composting (Kananam et al. 2011; Mohammad et al. 2013). Generally, the composting process is applied to decompose and stabilize organic solid wastes, including yard wastes, agricultural crops, food wastes, manure, municipal solid wastes, sewage and industrial sludge (Khamforoush et al. 2013). Composting period of organic matters may vary from 10 days to 3 months (and sometimes more), depending on the characteristics of the solid wastes (Makan et al. 2014). The latest research found that composting of empty fruit bunches together with palm oil mill effluent and compatible multi-enzymatic fungal system produced matured compost with $\mathrm{C} / \mathrm{N}$ ratio of 17 (Mohammad et al. 2013). Nevertheless, installing compost technology alone is troublesome due to the characteristics of raw palm oil mill effluent; plus composting with this effluent requires additional microbes and enzymes for maintaining product quality and water content (Yoshizaki et al. 2013). Although composting of empty fruit bunches under aerobic conditions is more effective, the process requires a turning machine and intensive labor (Kananam et al. 2011). Until now, most of the palm oil millers do not have a clear direction to choose the most suitable technology for managing their empty fruit bunches; thus, they continue practicing the typical disposal method through burning or direct land application as mulch (Chiew and Shimada 2013).

Vermicomposting was investigated in the present study as an alternative method to manage empty fruit bunches in a more sustainable way. Vermicomposting is a composting process involving the interaction of earthworms and 
microorganisms to produce humus-like material known as vermicompost. Vermicomposting is especially favored to be used when space is at a premium (unavailability of larger spaces for composting in pits) (Sim and Wu 2010). The vermicompost is a stabilized product having greater contents of the most needed nutrients in the forms that are readily taken up by the plants. Furthermore, vermicompost is less likely than synthetic fertilizer to produce salinity stress in the soil container (Chaoui et al. 2003). This technology has been used to stabilize biodegradable wastes generated from different industries such as oil palm industry (Sabrina et al. 2009; Nahrul Hayawin et al. 2010), olive oil industry (Masciandaro et al. 2010), paper mill industry (Kaur et al. 2010), soybean oil industry (Lim et al. 2011), sugar cane industry (Suthar 2010b) and others.

To the best of our knowledge, limited study has been devoted to the vermicomposting process of biomass residues generated from oil palm industry. Therefore, the aim of this study was to investigate the suitability of Eudrilus eugeniae in vermicomposting of empty fruit bunches, which were spiked with cow dung in different weight ratio under laboratory condition in order to produce the most superior quality of vermicompost within 12 weeks. The best ratio between cow dung and empty fruit bunches in providing the most appropriate environment for E. eugeniae to live in was investigated in the present study. Also, the nutrient qualities of the end product or vermicompost and growth parameters of E. eugeniae were explored using this study. The vermicomposting experiments were conducted in Chemical Engineering Laboratory at Monash University Malaysia between January and April, 2012.

\section{Materials and methods}

Earthworm and collection of organic waste

Epigeic earthworms of E. eugeniae used in this study were purchased from ESI Agrotech, Malaysia. E. eugeniae was selected in this study because the productivity of $E$. $e u$ geniae is high and thus able to convert the biodegradable solid wastes more effectively (Domínguez et al. 2001). Furthermore, recent study showed that the surface-dwelling mode of life guarded the epigeic earthworms against their exposure to toxicity (Suthar 2014).

Empty fruit bunches was procured from Hulu Langat Palm Oil Mill, Selangor, Malaysia. They were dried in direct sunlight for 1 week with periodic flipping and stored for further uses in this study. Raw cow dung was obtained from Selangor, Malaysia. The dung was leached with distilled water in the ratio of 1:10 (dried weight/volume). The leached cow dung was dried in an oven at $37^{\circ} \mathrm{C}$ for $48 \mathrm{~h}$ with periodic flipping and stored for further use as an
Table 1 Chemical characteristic of empty fruit bunches and cow dung (mean $\pm \mathrm{SD}, n=3$ )

\begin{tabular}{lcc}
\hline Parameters & $\begin{array}{l}\text { Empty fruit } \\
\text { bunches }\end{array}$ & \multicolumn{1}{c}{ Cow dung } \\
\hline $\mathrm{pH}$ & $6.32 \pm 0.08$ & $6.87 \pm 0.01$ \\
Total carbon $(\mathrm{g} / \mathrm{kg})$ & $446.88 \pm 45.28$ & $268.49 \pm 35.12$ \\
Total Kjeldahl nitrogen $(\mathrm{g} /$ & $3.00 \pm 0.00$ & $17.81 \pm 0.55$ \\
$\quad \mathrm{~kg})$ & & \\
$\mathrm{C} / \mathrm{N}$ ratio & $148.96 \pm 14.29$ & $15.08 \pm 3.42$ \\
Electrical conductivity $(\mu \mathrm{S} /$ & $781.50 \pm 84.55$ & $653.47 \pm 29.54$ \\
$\quad \mathrm{~cm})$ & & \\
Phosphorus $(\mathrm{g} / \mathrm{kg})$ & $0.66 \pm 0.08$ & $0.92 \pm 0.13$ \\
Potassium $(\mathrm{g} / \mathrm{kg})$ & $11.21 \pm 0.59$ & $3.51 \pm 0.60$ \\
Magnesium $(\mathrm{g} / \mathrm{kg})$ & $1.11 \pm 0.08$ & $9.03 \pm 0.14$ \\
Calcium $(\mathrm{g} / \mathrm{kg})$ & $1.60 \pm 0.13$ & $20.74 \pm 4.75$ \\
\hline
\end{tabular}

Table 2 Description of different treatment used for vermicomposting

\begin{tabular}{ll}
\hline Treatment & Treatment description \\
\hline E & Empty fruit bunches alone \\
E3:D1 & 3 parts of empty fruit bunches: 1 part of cow dung \\
E2:D1 & 2 parts of empty fruit bunches: 1 part of cow dung \\
E1:D1 & 1 part of empty fruit bunches: 1 part of cow dung \\
E1:D2 & 1 part of empty fruit bunches: 2 parts of cow dung \\
E1:D3 & 1 part of empty fruit bunches: 3 parts of cow dung \\
\hline
\end{tabular}

amendment. The chemical characteristics of empty fruit bunches and cow dung used in this study are presented in Table 1.

\section{Experimental set up}

Initial carbon-to-nitrogen ratio $(\mathrm{C} / \mathrm{N}$ ratio) of the feedstock is known to affect the growth and reproduction of the earthworms (Yadav and Garg 2011). Previous study showed that high $\mathrm{C} / \mathrm{N}$ ratio of empty fruit bunches (Table 1) did not favor the growth of earthworms (Sabrina et al. 2009). Hence, cow dung with a lower $\mathrm{C} / \mathrm{N}$ ratio (Table 1) was chosen as an amendment in vermicomposting of empty fruit bunches to readjust the $\mathrm{C} / \mathrm{N}$ ratio of the initial feedstock or waste mixture. Furthermore, cow dung is considered as one of the most suitable amendments used in vermicomposting process (Vig et al. 2011). In the present study, five different combinations of waste mixture, consisted of empty fruit bunches and cow dung (dried weight proportions), were prepared (Table 2), so that the waste mixtures possessed various initial $\mathrm{C} / \mathrm{N}$ ratios, which were lower than empty fruit bunches alone. Controls (without earthworms) were also prepared for all treatments.

About $200 \mathrm{~g}$ of feedstock (dried weight basis) was filled into a rectangular vermireactor $\left(17 \times 14 \times 12 \mathrm{~cm}^{3}\right)$. Ten 
nonclitellated epigeic earthworms with an average weight of $0.30 \mathrm{~g}$ per worm were introduced into each vermireactor. The feedstock was moistened with distilled water to obtain an appropriate moisture level for the earthworms to survive. Besides, the moisture content was maintained at $60-80 \%$ by periodic sprinkling of adequate quantity of distilled water on the feedstock throughout the study. The experimental beddings were conducted in triplicate for each treatment. The vermireactors were kept in the dark at room temperature of $25 \pm 2{ }^{\circ} \mathrm{C}$, which is the optimum temperature of E. eugeniae (Lim et al. 2011).

The duration of the vermicomposting process was 12 weeks. Feedstocks and vermicomposts were collected at 0 and 12 weeks, respectively, from each vermireactor in order to measure the changes of chemical characteristics of the samples. The samples were oven-dried at $60{ }^{\circ} \mathrm{C}$ for $48 \mathrm{~h}$, ground and stored in polythene bags at $4{ }^{\circ} \mathrm{C}$ for further physicochemical analysis.

The growth, population and live weigh of earthworms were recorded weekly in all vermireactors by following the method described by Lim et al. (2011). Earthworms were separated from the substrate material by hand-sorting method. Then, they were washed in distilled water to remove any adhering materials from their bodies and subsequently drying them on paper towels before weighing them on a live-weight basis without correction of their gut content.

\section{Chemical analysis}

The electrical conductivity and $\mathrm{pH}$ were measured using a digital conductivity meter (Schott Instruments Handylab LF11/set) and $\mathrm{pH}$ meter (Mettler Toledo SevenEasy), respectively, in 1:10 (weight/volume) aqueous solution (deionized water) (Khwairakpam and Bhargava 2009). Total organic carbon was determined using a wet chemistry method by a TOC analyzer (Aurora Solid1030). Total Kjeldahl nitrogen was measured using the method described by Shaw and Beadle (1949). Total contents of calcium, magnesium, phosphorus and potassium were measured by the ignition method using an atomic absorption spectrophotometer of Agilent Technologies 200 SeriesAA. All the samples were analyzed in triplicate.

\section{Results and discussion}

Growth of E. eugeniae in different treatments

The productivity of earthworm is an important indicator to evaluate the progress of vermicomposting process (Suthar 2010b). In this study, the growth of earthworms among different treatments was closely related to the feed quality

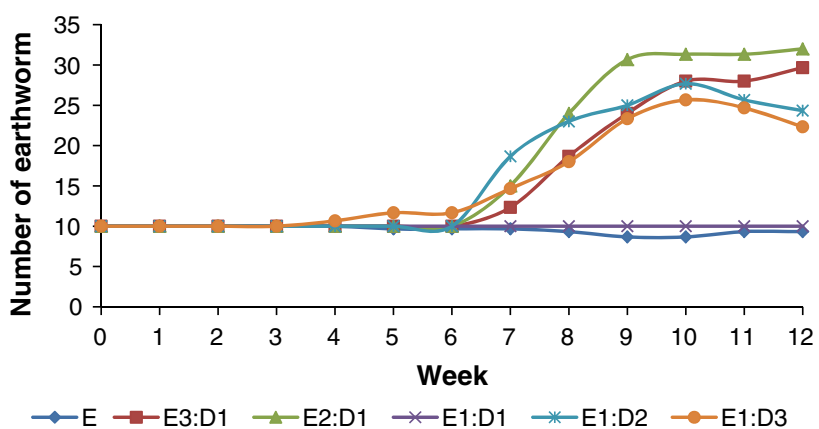

Fig. 3 Number of E. eugeniae in different treatments. The number of earthworms is the average value of triplicate tests

(Lim et al. 2012). Figure 3 shows that the number of earthworms started increasing on week 6 for treatments of E1:D2 (18 earthworms), E2:D1 (15 earthworms), E1:D3 (14 earthworms) and E3:D1 (12 earthworms). The maximum number of earthworms (32) was noticed in the treatment of E2:D1 (Fig. 3). No increase in earthworms quantities was observed in treatments with higher composition of empty fruit bunches, such as treatments of $E$ and E1:D1. Empty fruit bunches could contain cellulose, hemicelluloses and lignin up to $39.8,17.3$ and $10.3 \%$, respectively (Park et al. 2013). Generally, waste with high lignin contents (such as empty fruit bunches in this study) is not favorable for most of the earthworms (Shak et al. 2014). Also, the high lignin contents in the waste inhibit microbial activities (Lim et al. 2012). Therefore, cow dung was acted as a complementary waste not only to reduce the processing time but also to improve the quality and successful conversion of wastes into vermicomposts (Vig et al. 2011).

The biomass of E. eugeniae in different treatment is shown in Table 3. As shown in Table 3, the highest earthworm biomass was observed in the treatment of E2:D1 (13.39 g). The lowest growth rate of earthworm was recorded in the treatment supplied with empty fruit bunches alone $(0.21 \mathrm{~g} /$ worm/day), and the highest was recorded in both treatments of E2:D1 and E1:D2 (0.54 g/worm/ day). It is hypothesized that the suitable proportion of cow dung and empty fruit bunches provided earthworms with sufficient amounts of easily degradable organic matter, which created an ideal environment for the growth and reproduction of earthworms (Nahrul Hayawin et al. 2010). An initial increase in biomass was followed by stabilization, and later, weight loss was observed in most of the treatments after 12 weeks of vermicomposting process (Table 3). The decrease in the biomass of earthworms could be due to the conversion of the wastes into vermicomposts, which did not support the growth of earthworms (Lim et al. 2011). Research done by Domínguez et al. 
Table 3 Earthworm productions during vermicomposting process (mean $\pm \mathrm{SD}, n=3$ )

\begin{tabular}{|c|c|c|c|c|}
\hline Treatment & $\begin{array}{l}\text { Initial biomass of earthworms } \\
(\mathrm{g})\end{array}$ & $\begin{array}{l}\text { Final biomass of earthworms } \\
(\mathrm{g})\end{array}$ & $\begin{array}{l}\text { Maximum biomass of } \\
\text { earthworm }(\mathrm{g})\end{array}$ & $\begin{array}{l}\text { Maximum growth rate } \\
\text { (g worm/day) }\end{array}$ \\
\hline $\mathrm{E}$ & $3.18 \pm 0.08$ & $9.71 \pm 0.52$ & $9.71 \pm 0.52$ & $0.21 \pm 0.10$ \\
\hline E3:D1 & $5.06 \pm 0.35$ & $10.01 \pm 0.42$ & $11.79 \pm 0.96$ & $0.42 \pm 0.09$ \\
\hline E2:D1 & $4.77 \pm 0.83$ & $10.6 \pm 0.06$ & $13.39 \pm 1.48$ & $0.54 \pm 0.09$ \\
\hline E1:D1 & $2.94 \pm 0.01$ & $11.97 \pm 0.33$ & $11.97 \pm 0.33$ & $0.44 \pm 0.02$ \\
\hline E1:D2 & $4.92 \pm 0.68$ & $10.02 \pm 0.18$ & $12.06 \pm 0.48$ & $0.54 \pm 0.08$ \\
\hline E1:D3 & $4.50 \pm 1.17$ & $9.35 \pm 0.08$ & $11.18 \pm 0.21$ & $0.53 \pm 0.06$ \\
\hline
\end{tabular}

(2001) also showed that when the earthworm population density exceeded 16 earthworms/100 g substrate, the earthworms were inclined to lose weight or result in death.

$\mathrm{pH}$ of the vermicompost

According to Khwairakpam and Bhargava (2009), pH shift in the vermicompost was dynamic and waste dependent. The initial $\mathrm{pHs}$ of all treatments were in the range between 6.32 and 6.79 (Table 4), which is an ideal $\mathrm{pH}$ range for the earthworms. After 12 weeks of vermicomposting process, the $\mathrm{pH}$ of the final vermicompost showed two different trends: The $\mathrm{pH}$ of the vermicompost was higher for the waste mixture with higher proportion of empty fruit bunches, while the $\mathrm{pH}$ of the vermicompost was lower than neutral for the waste mixture with higher proportion of cow dung (Table 4). Hence, the difference in $\mathrm{pH}$ among the different treatments could be explained by the quality of the wastes, which affects the mineralization process and species of intermediate compounds during the vermicomposting process (Gupta and Garg 2008). As mentioned earlier, the final $\mathrm{pH}$ of the vermicomposts with higher proportion of empty fruit bunches showed alkaline conditions after 12 weeks of vermicomposting process (Table 4). Study conducted by Lim et al. (2012) showed that the activity of earthworms did not affect the $\mathrm{pH}$ of organic substrates but they did exert physiological control such as secreting intestinal calcium and excreting $\mathrm{NH}_{4}-\mathrm{N}$ for maintaining neutral $\mathrm{pH}$ in their digestive tract. Hence, the increase in $\mathrm{pH}$ in the final vermicompost was mainly due to the degradation of short-chained fatty acids and intensive mineralization of nitrogen by the microbes (Tognetti et al. 2007). Besides, an increase in $\mathrm{pH}$ in the final vermicompost was due to the presence of ammonia. The ammonia was released into the vermicompost when the excess of organic nitrogen in the feedstock was not required by the microbes (Singh et al. 2010).

According to Yadav and Garg (2011), the acceptable $\mathrm{pH}$ range for earthworms and microorganisms activity during vermicomposting is 5.5-8.5, in which case the optimum $\mathrm{pH}$ is neutral or near neutral. The vermicomposting process will only be slowed down drastically (due to the mortality of the earthworms) when the $\mathrm{pH}$ of the waste is lower than 5 (Sim and $\mathrm{Wu}$ 2010). Overall, the pHs of all the initial feedstocks and final vermicomposts in this study were in the ranges of 6.32-6.79 and 6.87-8.54, respectively (Table 4). Thus, it could be deduced that all treatments investigated in this study showed satisfactory $\mathrm{pH}$ values for encouraging the growth of E. eugeniae.

\section{Electrical conductivity of the vermicompost}

Electrical conductivity reflects the total amount of dissolved ions available in the water or the salinity of an organic amendment (Lazcano et al. 2008). Table 4 shows the comparison of electrical conductivity between the final vermicompost and control for all the treatments investigated up to the duration of 12 weeks. After 12 weeks of vermicomposting process, electrical conductivity has shown increases (as compared to the initial feedstocks) in all treatments except the treatment of E2:D1. The increase in electrical conductivity was mainly due to the loss of organic matter and the release of different soluble salts in available form (such as phosphate, ammonium and potassium) from the activity of earthworms and microorganism (Karmegam and Daniel 2009; Khwairakpam and Bhargava 2009). Fernández-Gómez et al. (2010b) reported that high electrical conductivity in vermicompost might not be favorable to the growth of earthworms. Their observation was in concurrent with the present study, showing that the treatment with the highest electrical conductivity (treatment with empty fruit bunches alone or E) discouraged the growth of earthworms (Fig. 3; Table 3). Study done by Guzyte et al. (2011) showed that an increase in salinity (or electrical conductivity) had harmful effect on the growth, mortality and reproduction of the earthworms. On the other hand, lower electrical conductivity was observed in the final vermicompost of E2:D1 treatment, representing the biotransformation of waste mixture into more stabilized form of vermicompost (Kaur et al. 2010). Lim et al. (2011) and Fernández-Gómez et al. (2013) also observed a decline in electrical conductivity in the vermicompost produced 


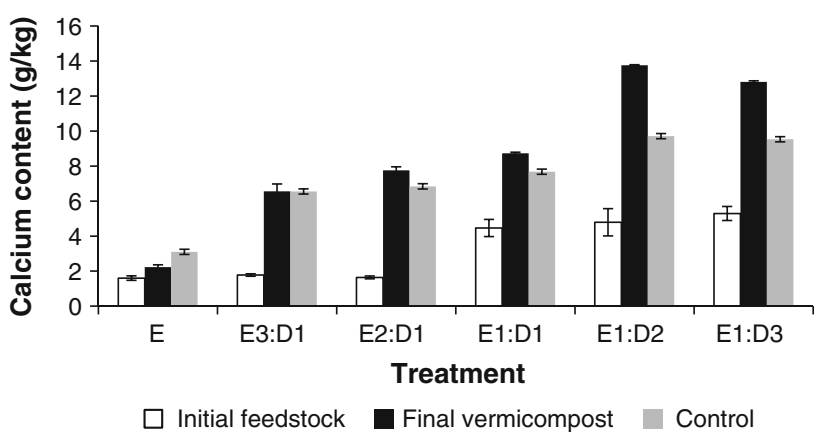

Fig. 4 Total calcium content of initial feedstock, final vermicompost and control in different treatments. The calcium content is the average value of triplicate tests

from soybean husk and greenhouse tomato-plant waste, respectively.

$\mathrm{C} / \mathrm{N}$ ratio of the vermicompost

$\mathrm{C} / \mathrm{N}$ ratio is one of the most important indicators to show the maturity and stabilization of fertilizer because plant cannot assimilate nitrogen unless the $\mathrm{C} / \mathrm{N}$ ratio is in the order of 20 or less (Khwairakpam and Bhargava 2009). Additionally, $\mathrm{C} / \mathrm{N}$ ratio is the most important factors determining the palatability of earthworm (Hendriksen 1990). All the initial $\mathrm{C} / \mathrm{N}$ ratios of the wastes in this study were in the range from 24.03 to 148.96 (Table 4). The variations of $\mathrm{C} / \mathrm{N}$ ratio in different treatments were due to the substrate quality used in this study. After 12 weeks of vermicomposting process, all the final vermicomposts showed a sharp decline in $\mathrm{C} / \mathrm{N}$ ratio with both treatments of $\mathrm{E} 2: \mathrm{D} 1$ and $\mathrm{E} 1: \mathrm{D} 2$ achieved $\mathrm{C} / \mathrm{N}$ ratio lower than 20 (Table 4). According to Lim et al. (2011), the combined activities between earthworms and microorganisms decreased the organic carbon levels from the wastes and enhanced the waste stabilization process by releasing carbon as carbon dioxide during the respiration process. In addition, the production of mucus and nitrogenous excreta by the earthworms would increase the level of nitrogen, thus reducing the $\mathrm{C} / \mathrm{N}$ ratio of the wastes (Lim et al. 2011). Controls were found to have a higher $\mathrm{C} / \mathrm{N}$ ratio as compared to most of the final vermicomposts after 12 weeks of vermicomposting process (Table 4). Ravi Kumar et al. (2009) revealed that with the help from the earthworms, nitrogen could be mineralized into a greater extent. Thus, $\mathrm{C} / \mathrm{N}$ ratio of the feedstocks could be greatly reduced during vermicomposting as compared to the conventional composting process (Suthar 2009). The highest decrease in $\mathrm{C} / \mathrm{N}$ ratio in final vermicompost occurred in the treatments of $\mathrm{E}$ $(-76.24 \%)$, followed by E2:D1 $(-68.58 \%)$, E3:D1 $(-65.29 \%)$, E1:D1 $(-63.29 \%)$, E1:D2 $(-36.72 \%)$ and 


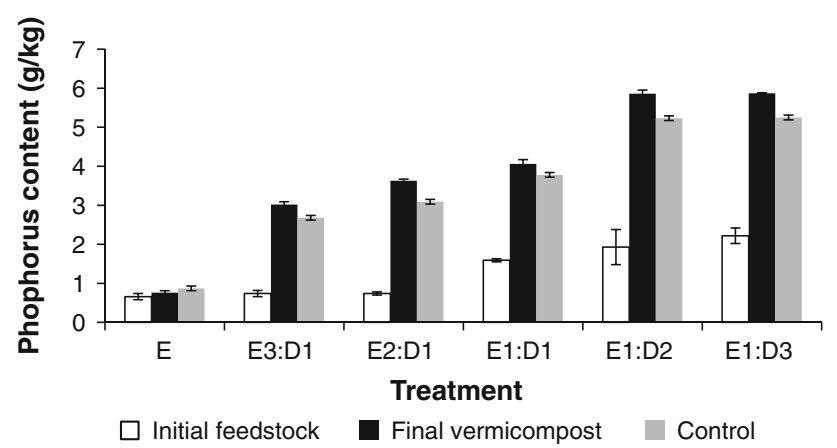

Fig. 5 Total phosphorus content of initial feedstock, final vermicompost and control for all treatments. The phosphorus content is the average value of triplicate tests

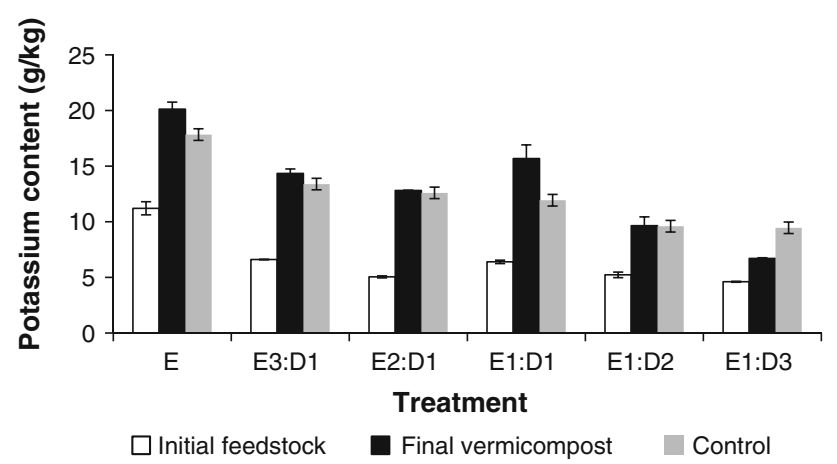

Fig. 6 Total potassium content of initial feedstock, final vermicompost and control for all treatments. The potassium content is the average value of triplicate tests

E1:D3 $(-11.24 \%)$. The $\mathrm{C} / \mathrm{N}$ ratios of the final vermicomposts were in the range of 18.53 (E2:D1) and 35.40 (E). Hence, it is suggested that empty fruit bunches amended with appropriate ratio of cow dung affected the telluric microflora, leading to enhanced decomposition process (Suthar 2008). The result obtained is concurrent with the earlier studies done by Ludibeth et al. (2012) and Shak et al. (2014) that vermicomposting could reduce the $\mathrm{C} / \mathrm{N}$ ratio of sewage sludge and rice straw, respectively, to a preferred level of below 20 .

Nutrient quality of the vermicompost

After 12 weeks of vermicomposting process, the waste was a stabilized and nutrient-rich material. The interactions between earthworms and microorganisms play an important role in the degradation of organic matter and enhancement of nutrients (Lim et al. 2011). Current study showed that E. eugeniae converted the wastes (especially the treatment of E2:D1) into fine granular fertilizer with high nutrient contents, which showed significant differences from the initial feedstocks. In the present study, higher proportions of cow dung (E1:D2 and E1:D3 treatments) generally led to higher contents of total calcium, phosphorus and magnesium in the final vermicomposts. Similar results were observed by Sierra et al. (2013) who concluded that vermicomposting enhanced end quality concerning calcium, phosphorus and magnesium contents, especially for treatments with high cattle manure contents.

Calcium is an important physiological supplement for organisms. Higher level of calcium in the vermicomposts indicated their potential as organic fertilizers in agronomy (Lim et al. 2011). As compared to the initial feedstocks (Fig. 4), the maximum increases in the total calcium content in the final vermicomposts were obtained from the treatments of E2:D1 $(+373.17 \%)$, followed by E3:D1 $(+268.54 \%)$, E1:D2 (+187.27 \%), E1:D3 (+142.16\%), E1:D1 $(+95.74 \%)$ and E $(+39.38 \%)$. Similar increase in total calcium in the vermicompost was reported by some researchers who used E. eugeniae in vermicomposting of agricultural wastes (Lim et al. 2011, 2012). For example, Lim et al. (2011) reported an increase in calcium content in the mixture of soybean husk and market-rejected papaya after 9 weeks of vermicomposting process using $E$. eugeniae. Besides, Lim et al. (2012) also found that E. eugeniae enabled the biotransformation of rice husk, which was mixed with an equal amount of market-refused papaya, into vermicompost with higher calcium content. The richness of organic wastes used as feedstocks is important in determining the final total calcium level in the vermicompost (Lim et al. 2014).

Phosphorus indicates the agronomic potential for crop production because phosphorus is an important nutrient, which is required for photosynthesis, energy transfer within plants as well as for good flowering and fruit growth (Lim et al. 2011). Although total phosphorus is required for assimilation of earthworms during vermicomposting process, the quantity required is usually very low as compared to the total quantity present in the feed material (Yadav et al. 2012). Figure 5 indicates the maximum increases in the total phosphorus content in the final vermicomposts were obtained from the treatments of E2:D1 $(+390.54 \%)$, followed by E3:D1 $(+308.11 \%)$, E1:D2 $(+203.63 \%)$, E1:D3 $(+164.41 \%), \quad$ E1:D1 $(+155.35 \%)$ and E $(+15.15 \%)$. Hait and Tare (2011) reported similar results during vermicomposting of waste activated sludge. Nayak et al. (2013) also observed a gradual increase in either total or available phosphorus in the waste mixtures (consisted of sewage sludge, cattle manure and saw dust) throughout the vermicomposting period of 45 days.

Potassium in fertilizer is widely studied because potassium improves the water usability of plant and enhances the growth of crop (Hejcman et al. 2012). By comparison, the maximum increases in the total potassium content in 
the final vermicomposts were obtained from the treatments of E2:D1 (+153.66 \%), followed by E1:D1 $(+145.16 \%)$, E3:D1 $(+117.10 \%)$, E1:D2 $(+84.51 \%), \mathrm{E}(+79.48 \%)$ and E1:D3 $(+45.55 \%)$. The potassium contents in the vermicomposts were higher than the controls (except E1:D3 treatment) after 12 weeks of vermicomposting process (Fig. 6). Recent study conducted by Lim et al. (2014) also found that the waste mixtures consisted of palm oil mill effluent and rice straw could be biotransformed by E. eugeniae into vermicomposts, which were richer in total potassium content than the initial waste mixtures or controls without earthworms. However, Sierra et al. (2013) reported that loss of total potassium was more evident in vermicomposts than in composts, in which case the potassium losses at the end of biodegradation of green wastes amended with cattle manure were 50 and $39 \%$ for vermicomposts and composts, respectively.

Magnesium is an important parameter for plant growth because magnesium is essential for chloroplasts, being the central element in chlorophyll, and acts as a cofactor in various enzymatic processes associated with photosynthesis, respiration and energetic metabolism (Ruan et al. 2011). Figure 7 shows that the maximum increases in total magnesium content in the final vermicomposts were obtained from the treatments of E2:D1 $(+370.93 \%)$, followed by E3:D1 $(+245.36 \%)$, E1:D2 $(+206.10 \%)$, E1:D3 $(+163.60 \%), \quad$ E1:D1 $(+83.58 \%)$ and E $(+55.86 \%)$. Some recent studies also indicated that the final vermicomposts contained higher total magnesium content after the earthworms were incorporated into biodegradation process of solid wastes (Domínguez and Gómez-Brandón 2013; Lim et al. 2014). Until now, the direct contribution of earthworm in magnesium metabolism is still unclear. It is hypothesized that fungal and microalgal hyphae, which easily colonize on freshly deposited worm casts, are contributing to trace level of magnesium in the final vermicompost (Suthar 2010b; Lim et al. 2012). Domínguez and Gómez-Brandón (2013) found that the presence of earthworms increased total magnesium content in the solid wastes over time but this effect was more obvious in the manure rather than sewage sludge. Also, Lim et al. (2014) found that the final vermicomposts which were derived from palm oil mill effluent after 6 weeks of vermicomposting had higher total magnesium contents when rice straw (rather than soil) was used as an amendment. Thus, the total magnesium content in the vermicompost might also be dependent on the type of waste or amendment used during vermicomposting process.

Generally, the overall increase in total nutrient contents in the vermicompost was due to the reduction in the weight of initial feedstock during vermicomposting process (Hait and Tare 2011). The concentration effect was caused by the

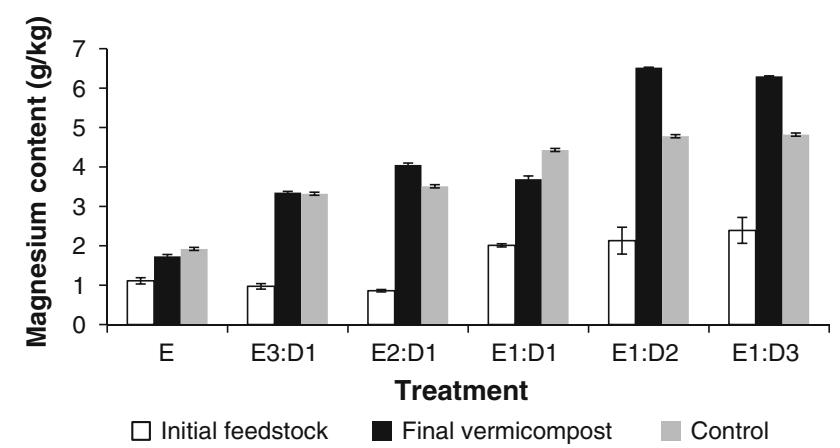

Fig. 7 Total magnesium content of initial feedstock, final vermicompost and control for all treatments. The magnesium content is the average value of triplicate tests
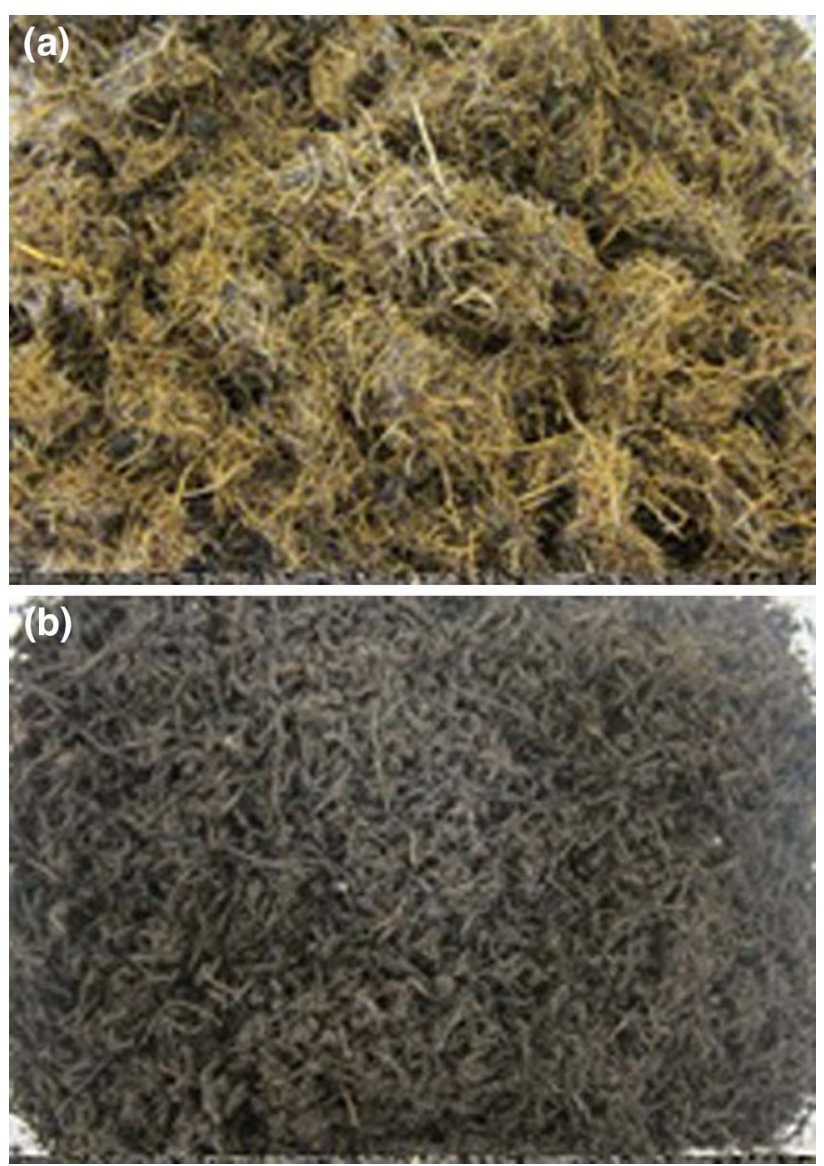

Fig. 8 Photo images of $\mathbf{a}$ initial waste mixture and $\mathbf{b}$ final vermicompost of E2:D1 treatment

degradation of organic matter, which reduced the volume of feedstock due to the release of carbon dioxide during vermicomposting process (Garg et al. 2012). Also, the total nutrient contents in the vermicomposts were higher than in the controls, indicating that earthworms accelerated the decomposition of organic matters. 

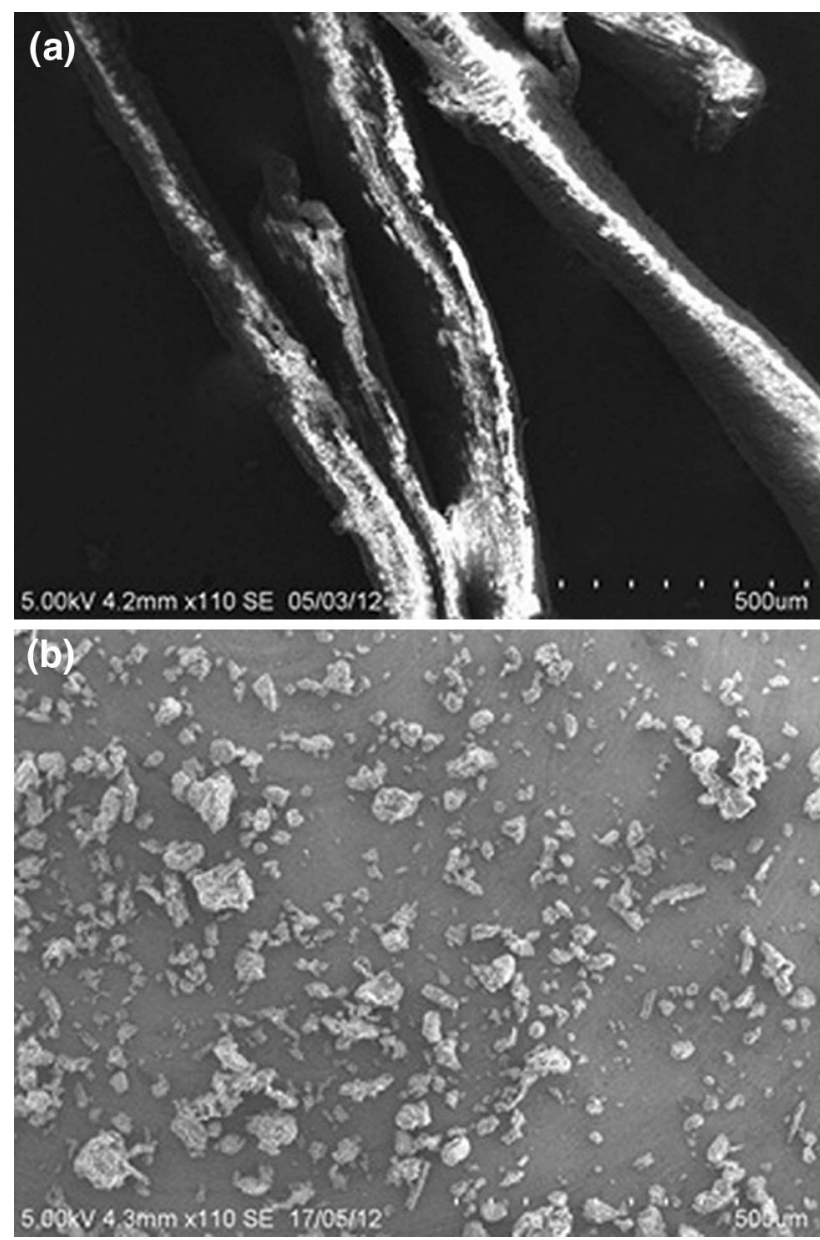

Fig. $9 \times 110$ magnification SEM images of a initial waste mixture and $\mathbf{b}$ final vermicompost of E2:D1 treatment

Physical structure of waste mixture and vermicompost

Among all the treatments investigated, treatment of E2:D1 provided the best quality of vermicompost (in terms of the lowest $\mathrm{C} / \mathrm{N}$ ratio and the highest percentage increase in nutrient contents) and encouraged the growth rate of $E$. eugeniae. Thus, qualitative evaluations of the final vermicompost produced from the treatment of E2:D1 were investigated in this study. Vermicompost in the treatment of E2:D1 exhibited greater surface area (Fig. 8b) as compared to initial waste mixture (Fig. 8a) because the vermicompost obtained was smaller in size with granular structure. Furthermore, the color of vermicompost was also darker as compared to the initial waste mixture. These observations were consistent with those reported by Yadav and Garg (2009) as well as Lim et al. (2012). However, some empty fruit bunch residues still could be detected in the final vermicompost (Fig. 8b), indicating that the initial waste mixture might not be fully vermicomposted. It is suggested that the duration of vermicomposting process
Table 5 Comparison between earlier and current study on vermicomposting of empty fruit bunches

\begin{tabular}{|c|c|c|c|}
\hline References & $\begin{array}{l}\text { Current } \\
\text { study }\end{array}$ & $\begin{array}{l}\text { Nahrul } \\
\text { Hayawin } \\
\text { et al. }(2010)\end{array}$ & $\begin{array}{l}\text { Sabrina et al. } \\
\text { (2009) }\end{array}$ \\
\hline $\begin{array}{l}\text { Earthworm } \\
\text { species }\end{array}$ & $\begin{array}{l}\text { Eudrilus } \\
\text { eugeniae }\end{array}$ & $\begin{array}{l}\text { Eudrilus } \\
\text { eugeniae }\end{array}$ & Eisenia fetida \\
\hline Amendment & Cow dung & - & Cow dung \\
\hline Precomposting & No & Yes & Yes (4 weeks) \\
\hline $\begin{array}{l}\text { Vermicomposting } \\
\text { duration }\end{array}$ & 12 weeks & 12 weeks & 12 weeks \\
\hline $\begin{array}{l}\text { Moisture content } \\
(\%)\end{array}$ & $75 \pm 10$ & $70 \pm 10$ & $80-85$ \\
\hline $\begin{array}{l}\mathrm{C} / \mathrm{N} \text { ratio of } \\
\text { vermicompost }\end{array}$ & 18.53 & $\sim 36.49$ & 12.91 \\
\hline $\begin{array}{l}\mathrm{pH} \text { of } \\
\text { vermicompost }\end{array}$ & 7.80 & 7.50 & 7.87 \\
\hline $\begin{array}{l}\text { Calcium content } \\
(\mathrm{g} / \mathrm{kg})\end{array}$ & 7.76 & - & 1.92 \\
\hline $\begin{array}{l}\text { Phosphorus } \\
\text { content }(\mathrm{g} / \mathrm{kg})\end{array}$ & 3.63 & 0.25 & 2.22 \\
\hline $\begin{array}{l}\text { Potassium content } \\
(\mathrm{g} / \mathrm{kg})\end{array}$ & 12.81 & 0.69 & 53.55 \\
\hline $\begin{array}{l}\text { Magnesium } \\
\text { content }(\mathrm{g} / \mathrm{kg})\end{array}$ & 4.05 & - & 3.00 \\
\hline Remarks & $\begin{array}{l}\text { Treatment } \\
\text { of E2:D1 }\end{array}$ & $\begin{array}{l}\text { Treatment of } \\
\text { empty fruit } \\
\text { bunches } \\
\text { only }\end{array}$ & $\begin{array}{l}\text { Stocking density of } \\
\text { treatment } 1: 6 \\
\text { (earthworm/ } \\
\text { media) ratio }\end{array}$ \\
\hline
\end{tabular}

could be extended to ensure complete biotransformation of empty fruit bunches into vermicompost using E. eugeniae.

The scanning electron microscopy (SEM) images of the initial waste mixture and final vermicompost are depicted in Fig. 9a, b, respectively. The SEM image shows that the initial waste mixture of E2:D1 treatment, which was mainly consisted of empty fruit bunches, had the form of long fiber (Fig. 9a). After 12 weeks of vermicomposting process, the vermicompost exhibited a distinct physical appearance as compared to the initial waste mixture, being more granular in shape with greater surface area in the final vermicompost (Fig. 9b). This structure possessed better permeability of water and ventilation, thus reducing soil agglomeration during the soil application process and making the final vermicompost to be suitable for organic fertilizer (Li et al. 2011).

Comparison between current and earlier research on vermicomposting of empty fruit bunches

Limited study is devoted to vermicomposting of biomass residues generated from oil palm mill. Nahrul Hayawin et al. (2010) carried out a research on vermicomposting of empty fruit bunches, oil palm trunk and oil palm frond 
Table 6 Pilot scale studies of agro-industrial wastes biodegradation using vermicomposting process

\begin{tabular}{|c|c|c|c|c|c|}
\hline Agro-industrial wastes & Earthworm & $\begin{array}{l}\text { Duration } \\
\text { (months) }\end{array}$ & $\begin{array}{l}\text { Initial quantity of } \\
\text { wastes }(\mathrm{kg})\end{array}$ & $\begin{array}{l}\text { Final } \mathrm{C} / \mathrm{N} \text { ratio of } \\
\text { vermicompost }\end{array}$ & References \\
\hline $\begin{array}{l}\text { Paper mill sludge: dairy sludge: cattle } \\
\text { manure }=1: 1: 3\end{array}$ & $\begin{array}{l}\sim 1.125 \mathrm{~kg} \text { of } \\
\text { E. andrei }\end{array}$ & 6 & $90^{\mathrm{a}}$ & 13 & Elvira et al. (1998) \\
\hline $\begin{array}{l}\text { Dry olive cake: municipal } \\
\quad \text { biosolids }=8: 1\end{array}$ & $\begin{array}{l}0.3 \mathrm{~kg} \text { of } E \text {. } \\
\text { andrei }\end{array}$ & 9 & 64 & 19 & Benítez et al. (2002) \\
\hline $\begin{array}{l}\text { Sewage sludge: sugarcane } \\
\text { trash }=3: 2\end{array}$ & $\begin{array}{l}\sim 0.288 \mathrm{~kg} \text { of } \\
\text { E. fetida }\end{array}$ & 3 & $50^{\mathrm{b}}$ & 7.40 & Suthar (2010a) \\
\hline Liquid paste of tomato-fruit wastes & $\begin{array}{l}0.5 \mathrm{~kg} \text { of } E . \\
\text { fetida }\end{array}$ & 5 & $10^{\mathrm{c}}$ & 11.7 & $\begin{array}{l}\text { Fernández-Gómez } \\
\text { et al. (2010a) }\end{array}$ \\
\hline $\begin{array}{l}\text { Pressmud: spent wash: cow } \\
\text { dung }=1.2: 1.8: 1\end{array}$ & $\begin{array}{l}200 \mathrm{~kg} \text { of } E \text {. } \\
\text { eugeniae }\end{array}$ & $3^{\mathrm{d}}$ & 4,000 & $\sim 8.56$ & Kumar et al. (2012) \\
\hline
\end{tabular}

a $90 \mathrm{~kg}$ of wastes were added after 2 and 4 months of vermicomposting

b $20 \mathrm{~kg}$ of wastes were added after 2 months of vermicomposting

${ }^{c}$ Fresh organic wastes were continuously added at $13.6 \mathrm{~kg} \mathrm{TOC}^{-3}$ per week

${ }^{\mathrm{d}}$ Preliminary decomposition (without earthworms) was attempted for 1.5 months

using E. eugeniae with a precomposting (the duration of pretreatment was not stated), and their results showed that empty fruit bunches were the best substrates for E. eugeniae. The result obtained by Nahrul Hayawin et al. (2010) showed that after 84 days of vermicomposting, $\mathrm{C} / \mathrm{N}$ ratio of the vermicomposts was still remained high at about 36.49 , indicating that the produced vermicomposts were not matured enough to be used as a suitable fertilizer because plants cannot assimilate nitrogen unless the $\mathrm{C} / \mathrm{N}$ ratio is in the order of 20 or less (Khwairakpam and Bhargava 2009). Earlier, Sabrina et al. (2009) carried out a research on vermicomposting of empty fruit bunches using three species of earthworms, namely Eisenia fetida, Pontoscolex corethrutus and Amynthas rodericensis, but only E. fetida was able to survive in empty fruit bunches. In order to produce vermicompost of $\mathrm{C} / \mathrm{N}$ ratio less than 20 , longer duration was suggested in which case a total of 16 weeks were needed, including 4 weeks of precomposting process (Table 5). Table 5 summarizes comparison results between the current and earlier research on vermicomposting of empty fruit bunches, further justifying that the current study was able to produce mature vermicomposts in a shorter period of time using E. eugeniae with suitable incorporation of cow dung. However, further research is required to investigate the cost-effective strategies for vermicomposting empty fruit bunches in larger scale, in which case vermicomposting has been proven successfully to biodegrade huge amounts of agro-industrial wastes (Table 6).

\section{Conclusion}

The present study provides a basis of empty fruit bunch reuse as a feedstock in vermicomposting process. After
12 weeks of vermicomposting process using E. eugeniae, the final vermicompost showed greater increases in plant nutrients, e.g., nitrogen, calcium, phosphorus, potassium and magnesium. Among all the treatments investigated, empty fruit bunches which were mixed with cow dung in the ratio of 2:1 (E2:D1 treatment) showed superior quality vermicompost with desired $\mathrm{C} / \mathrm{N}$ ratio at 18.53 and the highest percentage increases in total nutritional status (calcium, $+373.17 \%$; phosphorus, $390.54 \%$; potassium, $+153.66 \%$; and magnesium, $370.93 \%$ ). Also, the treatment of E2:D1 encouraged the growth of earthworms in terms of the maximum biomass of earthworms $(13.39 \mathrm{~g})$ and number of earthworms (32). In short, this study suggests that the empty fruit bunches which were mixed with an appropriate ratio of cow dung could be easily vermicomposted by E. eugeniae and the vermicompost produced could be utilized as an efficient organic fertilizer for sustainable land restoration practices.

Acknowledgments The authors would like to thank the Department of Higher Education, Malaysia, for sponsoring this research work under Fundamental Research Grant Scheme of FRGS/1/2013/ STWN03/MUSM/02/1. In addition, the authors would like to thank Monash University, Sunway campus, for providing P. N. Lim with a PhD scholarship.

\section{References}

Abdullah SSS, Hassan MA, Shirai Y, Funaoka M, Shinano T, Idris A (2009) Effect of solvent pre-treatment on lignophenol production from oil palm empty fruit bunch fibres. J Oil Palm Res 21:700-709

Abdullah N, Gerhauser H, Sulaiman F (2010) Fast pyrolysis of empty fruit bunches. Fuel 89(8):2166-2169

Abu Bakar NK, Zanirun Z, Abd-Aziz S, Ghazali FM, Hassan MA (2012) Production of fermentable sugars from oil palm empty fruit bunch using crude cellulase cocktails with trichoderma 
asperellum UPM1 and Aspergillus fumigatus UPM2 for bioethanol production. BioResources 7(3):3627-3639

Alam MZ, Bari MN, Muyiba SA, Jamal P, Mamum AA (2010) Solid state bioconversion of oil palm empty fruit bunches for production of citric acid by wild strains of Aspergillus niger. Food Biotechnol 24(1):19-36

Bakar AA, Keat TB, Hassan A (2010) Tensile properties of a poly (vinyl chloride) composite filled with poly (methyl methacrylate) grafted to oil palm empty fruit bunches. J Appl Polym Sci 115(1):91-98

Benítez E, Sainz H, Melgar R, Nogales R (2002) Vermicomposting of a lignocellulosic waste from olive oil industry: a pilot scale study. Waste Manag Res 20(2):134-142

Chaoui HI, Zibilske LM, Ohno T (2003) Effects of earthworm casts and compost on soil microbial activity and plant nutrient availability. Soil Biol Biochem 35(2):295-302

Chiew YL, Shimada S (2013) Current state and environmental impact assessment for utilizing oil palm empty fruit bunches for fuel, fiber and fertilizer - a case study of Malaysia. Biomass Bioenergy 51:109-124

Chong PS, Jahim JM, Harun S, Lim SS, Mutalib SA, Hassan O, Nor MTM (2013) Enhancement of batch biohydrogen production from prehydrolysate of acid treated oil palm empty fruit bunch. Int J Hydrogen Energy 38(22):9592-9599

Domínguez J, Gómez-Brandón M (2013) The influence of earthworms on nutrient dynamics during the process of vermicomposting. Waste Manag Res 31(8):859-868

Domínguez J, Edward CA, Ashby J (2001) The biology and population dynamics of Eudrilus eugeniae (Kinberg) (Oligochaeta) in cattle waste solids. Pedobiologia 45(4):341-353

Elvira C, Sampedro L, Benítez E, Nogales R (1998) Vermicomposting of sludges from paper mill and dairy industries with Eisenia andrei: a pilot-scale study. Bioresour Technol 63(3):205-211

Fernández-Gómez MJ, Nogales R, Insam H, Romero E, Goberna M (2010a) Continuous-feeding vermicomposting as a recycling management method to revalue tomato-fruit wastes from greenhouse crops. Waste Manag 30(12):2461-2468

Fernández-Gómez MJ, Romero E, Nogales R (2010b) Feasibility of vermicomposting for vegetable greenhouse waste recycling. Bioresour Technol 101(24):9654-9660

Fernández-Gómez MJ, Díaz-Raviña M, Romero E, Nogales R (2013) Recycling of environmentally problematic plant wastes generated from greenhouse tomato crops through vermicomposting. Int J Environ Sci Technol 10(4):697-708

Firoozian P, Bhat IUH, Khalil HPSA, Noor AM, Akil HM, Bhat AH (2011) High surface area activated carbon prepared from agricultural biomass: empty fruit bunch (EFB), bamboo stem and coconut shells by chemical activation with $\mathrm{H}_{3} \mathrm{PO}_{4}$. Mater Technol 26(5):222-228

Garg VK, Suthar S, Yadav A (2012) Management of food industry waste employing vermicomposting technology. Bioresour Technol 126(1):237-443

Gupta R, Garg V (2008) Stabilization of primary sewage sludge during vermicomposting. J Hazard Mater 153(3):1023-1030

Guzyte G, Sujetoviene G, Zaltauskaite J (2011) Effects of salinity on earthworm (Eisenia fetida). In: The 8th international conference of environmental engineering. Vilnius, Lithuania 19-20 May

Hait S, Tare V (2011) Optimizing vermistabilization of waste activated sludge using vermicompost as bulking material. Waste Manag 31(3):502-511

Hejcman M, Křiš̌tálová V, Červená K, Hrdličková J, Pavlů V (2012) Effect of nitrogen, phosphorus and potassium availability on mother plant size, seed production and germination ability of Rumex crispus. Weed Res 52(3):260-268
Hendriksen NB (1990) Leaf litter selection by detritivore and geophagous earthworms. Biol Fert Soils 10(1):17-21

Kananam W, Suksaroj TT, Suksaroj C (2011) Biochemical changes during oil palm (Elaeis guineensis) empty fruit bunches composting with decanter sludge and chicken manure. Sci Asia 37(1):17-23

Karmegam N, Daniel T (2009) Investigating efficiency of Lampito mauritti (Kinberg) and Perionyx ceylanensis (Michaelsen) for vermicomposting of different types of organic substrate. Environmentalist 29(3):287-300

Kaur A, Singh J, Vig AP, Dhaliwal SS, Rup PJ (2010) Cocomposting with and without Eisenia fetida for conversion of toxic paper mill sludge to a soil conditioner. Bioresour Technol 101(21):8192-8198

Khamforoush M, Bijan-Manesh M-J, Hatami T (2013) Application of the Haug model for process design of petroleum hydrocarboncontaminated soil bioremediation by composting process. Int $\mathrm{J}$ Environ Sci Technol 10(3):533-544

Khwairakpam M, Bhargava R (2009) Vermitechnology for sewage sludge recycling. J Hazard Mater 161(2-3):948-954

Kumar VV, Shanmugaprakash M, Aravind J, Namasivayam SKR (2012) Pilot-scale study of efficient vermicomposting of agroindustrial wastes. Environ Technol 33(9):975-981

Lazcano C, Góemz-Brandón M, Domínguez J (2008) Comparison of the effectiveness of composting and vermicomposting for the biological stabilization of cattle manure. Chemosphere 72(7):1013-1019

Li X, Xing M, Yang J, Huang Z (2011) Compositional and functional features of humic-acid like fractions from vermicomposting of sewage sludge and cow dung. J Hazard Mater 185(2-3):740-748

Lim PN, Wu TY, Sim EYS, Lim SL (2011) The potential reuse of soybean husk as feedstock of Eudrilus eugeniae in vermicomposting. J Sci Food Agric 91(14):2637-2642

Lim SL, Wu TY, Sim EYS, Lim PN, Clarke C (2012) Biotransformation of rice husk into organic fertilizer through vermicomposting. Ecol Eng 41:60-64

Lim SL, Wu TY, Clarke C (2014) Treatment and biotransformation of highly polluted agro-industrial wastewater from a palm oil mill into vermicompost using earthworms. J Agric Food Chem 62(3):691-698

Ludibeth S, Marina I, Vicenta ES (2012) Vermicomposting of sewage sludge: earthworm population and agronomic advantages. Compost Sci Util 20(1):11-17

Makan A, Assobhei O, Mountadar M (2014) Initial air pressure influence on in-vessel composting for the biodegradable fraction of municipal solid waste in Morocco. Int J Environ Sci Technol 11(1):53-58

Masciandaro G, Bianchi V, Macci C, Doni S, Ceccanti B, Iannelli R (2010) Potential of on-site vermicomposting of sewage sludge in soil quality improvement. Desalin Water Treat 23(1-3):123-128

Mohammad N, Alam MZ, Kabashi NA (2013) Development of composting process of oil palm industrial wastes by multienzymatic fungal system. $\mathbf{J}$ Mater Cycles Waste Manag 15(3):348-356

MPOB (2012) Sectoral status 2012: FFB processed by mill 2012. Economic and Industry Development Division, Malaysian Palm Oil Board. http://bepi.mpob.gov.my. Accessed 12 July 2013

Nahrul Hayawin Z, Abdul Khalil HPS, Jawaid M, Hakimi Ibrahim M, Astimar AA (2010) Exploring chemical analysis of vermicompost of various oil palm fibre wastes. Environmentalist 20(3):273-278

Nayak AK, Varma VS, Kalamdhad AS (2013) Effects of various C/N ratios during vermicomposting of sewage sludge using Eisenia fetida. J Environ Sci Technol 6(2):63-78 
Nouri J, Nouri N, Moeeni M (2012) Development of industrial waste disposal scenarios using life-cycle assessment approach. Int J Environ Sci Technol 9(3):417-424

Park JM, Oh B-R, Seo J-W, Hong W-K, Yu A, Sohn J-H, Kim CH (2013) Efficient production of ethanol from empty palm fruit bunch fibers by fed-batch simultaneous saccharification and fermentation using Saccharomyces cerevisiae. Appl Biochem Biotechnol 170(8):1807-1814

Pleanjai S, Gheewala S, Savitri G (2004) Environmental evaluation of biodiesel production from palm oil in a life cycle perspective. In the Joint International conference on Sustainable Energy and Environment. Hua Hin, Thailand 1-3 December

Ravi Kumar P, Jayaram A, Somashekar RK (2009) Assessment of the performance of different compost models to manage urban household organic solid wastes. Clean Technol Environ Policy 11(4):473-484

Ruan J, Ma L, Yang Y (2011) Magnesium nutrition on accumulation and transport of amino acids in tea plants. J Sci Food Agric 97(7):1375-1383

Sabrina DT, Hanafi MM, Mahmud TMM, Nor Azwady AA (2009) Vermicomposting of oil palm empty fruit bunch and its potential in supplying of nutrients for crop growth. Compost Sci Util 17(1):61-68

Samsuri AW, Sadegh-Zadeh F, She-Bardan BJ (2014) Characterization of biochars produced from oil palm and rice husks and their adsorption capacities for heavy metals. Int J Environ Sci Technol 11(4):967-976

Shak KPY, Wu TY, Lim SL, Lee CA (2014) Sustainable reuse of rice residues as feedstocks in vermicomposting for organic fertilizer production. Environ Sci Pollut Res 21(2):1349-1359

Shaw J, Beadle LC (1949) A simplified ultra-micro Kjeldahl method for estimation of protein and total nitrogen in fluid samples of less than $1.0 \mu$ l. J Exp Biol 26(1):15-23

Sierra J, Desfontaines L, Faverial J, Loranger-Merciris G, Boval M (2013) Composting and vermicomposting of cattle manure and green wastes under tropical conditions: carbon and nutrient balances and end-product quality. Soil Res 51(2):142-151

Sim EYS, Wu TY (2010) The potential reuse of biodegradable municipal solid wastes (MSW) as feedstock in vermicomposting. J Sci Food Agric 90(13):2153-2162

Singh J, Kaur A, Vig AP, Rup PJ (2010) Role of Eisenia fetida in rapid recycling of nutrients from bio-sludge of beverage industry. Ecotoxicol Environ Saf 73(3):430-435

Stichnothe H, Schuchardt F (2011) Life cycle assessment of two palm oil production systems. Biomass Bioenergy 35(9):3976-3984

Suthar S (2008) Bioconversion of postharvest crop residues and cattle shed manure into value-added products using earthworm Eudrilus eugeniae Kinberg. Ecol Eng 32(3):206-214

Suthar S (2009) Bioremediation of agricultural wastes through vermicomposting. Biorem J 13(1):21-28

Suthar S (2010a) Pilot-scale vermireactors for sewage sludge stabilization and metal remediation process: comparison with small-scale vermireactors. Ecol Eng 36(5):703-712
Suthar S (2010b) Recycling of agro-industrial sludge through vermitechnology. Ecol Eng 36(8):1028-1036

Suthar S (2014) Toxicity of methyl parathion on growth and reproduction of three ecologically different tropical earthworms. Int J Environ Sci Technol 11(1):191-198

Tan HT, Dykes GA, Wu TY, Siow LF (2013) Enhanced xylose recovery from oil palm empty fruit bunch by efficient acid hydrolysis. Appl Biochem Biotechnol 170(7):1602-1613

Tognetti C, Mazzarino MJ, Laos F (2007) Cocomposting biosolids and municipal organic waste: effects of process management on stabilization and quality. Biol Fertil Soils 43(4):387-397

USDA (2012) Malaysia: stagnating palm oil yields impede growth. United States Department of Agriculture, Foreign Agricultural Service. http://www.pecad.fas.usda.gov/highlights/2012/12/ Malaysia. Accessed 12 July 2013

Vig AP, Singh J, Wani SH, Singh Dhaliwal S (2011) Vermicomposting of tannery sludge mixed with cattle dung into valuable manure using earthworm Eisenia fetida (Savigny). Bioresour Technol 102(17):7941-7945

Wu TY, Mohammad AW, Md Jahim J, Anuar N (2009) A holistic approach to managing palm oil mill effluent (POME): biotechnological advances in the sustainable reuse of POME. Biotechnol Adv 27(1):40-52

Wu TY, Mohammad AW, Md Jahim J, Anuar N (2010) Pollution control technologies for the treatment of palm oil mill effluent (POME) through end-of-pipe processes. J Environ Manag 91(7):1467-1490

Yadav A, Garg VK (2009) Feasibility of nutrient recovery from industrial sludge by vermicomposting technology. J Hazard Mater 168(1):262-268

Yadav A, Garg VK (2011) Industrial wastes and sludges management by vermicomposting. Rev Environ Sci Bio-Technol 10(3):243276

Yadav KD, Tare V, Mansoor Ahammed M (2012) Integrated composting-vermicomposting process for stabilization of human faecal slurry. Ecol Eng 47:24-29

Yoshizaki T, Shirai Y, Hassan MA, Baharuddin AS, Abdullah NMR, Sulaiman A, Busu Z (2013) Improved economic viability of integrated biogas energy and compost production for sustainable palm oil mill management. J Clean Prod 44:1-7

Zaman AU (2013a) Identification of waste management development drivers and potential emerging waste treatment technologies. Int J Environ Sci Technol 10(3):455-464

Zaman AU (2013b) Life cycle assessment of pyrolysis-gasification as an emerging municipal solid waste treatment technology. Int $\mathbf{J}$ Environ Sci Technol 10(5):1029-1038

Zhao SL, Shang XJ, Duo LA (2013) Effects of ethylenediaminetetraacetic acid and ammonium sulfate on $\mathrm{Pb}$ and $\mathrm{Cr}$ distribution in Kochia scoparia from compost. Int J Environ Sci Technol. doi:10.1007/s13762-013-0426-6 